\title{
Pengaruh Terapi Individu Generalis Dengan Pendekatan Strategi Pelaksanaan Komunikasi Terhadap Frekuensi Halusinasi Pada Pasien Halusinasi
}

\author{
Wan Muharyati ${ }^{a}$,Esi Afriyanti ${ }^{b}$, Adelse Prima Mulya $^{\mathrm{b}}$ \\ ${ }^{a}$ RSJ H.B Saanin Padang

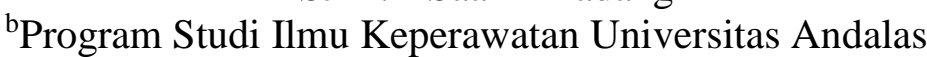 \\ E-mail :apm44@rocketmail.com
}

\begin{abstract}
One of non-pharmacological therapies that can be used to reduce the frequency of hallucinations is general individual therapy by the implementation of communication strategies. The purpose of this study was to determine the effect of general individual therapy in reducing the frequency of hallucinations of patients at RSJ. H.B Saanin Padang. This study used a Quasi-experiment in one group (one group pre test - post test design). Sampling was taken by purposive sampling. The samples of this study were to 13 people. Samples were provided by individual therapy with the implementation of communications strategy approach for 14 days. After that, samples were measured with regularly interview. This data was then analyzed using the Wilcoxon test with 95\% degree of confidence. Wilcoxon test results obtained $p$-value $=0.001$. This result showed that individual therapy approach to the implementation of communication strategies was effective in reducing the frequency of hallucinations of patients with hallucinations in the psychiatric hospital H.B Saanin Padang
\end{abstract}

Key words: hallucination, communication, general individual therapy

\begin{abstract}
Abstrak: Salah satu terapi non farmakologi yang dapat digunakan untuk mengurangi frekuensi halusinasi adalah terapi individu generalis dengan pendekatan strategi pelaksanaan komunikasi. Tujuan dari penelitian ini untuk mengetahui pengaruh terapi individu dalam mengurangi frekuensi halusinasi pada pasien halusinasi di RSJ. H.B Saanin Padang. Penelitian ini menggunakan Quasi Eksperimen dalam satu kelompok (one group pre test post test design). Pengambilan sampel dilakukan secara purposive sampling. Sampel dalam penelitian ini berjumlah 13 orang. Sampel diberikan terapi individu generalis dengan pendekatan strategi pelaksanaan komunikasi selama 14 hari. Setelah itu frekuensi halusinasi pasien diukur dengan menggunakan wawancara terstruktur. Data ini kemudian dianalisis dengan menggunakan uji wilcoxon dengan derajat kepercayaan 95\%. Hasil uji wilcoxon didapatkan nilai $\mathrm{p}=0,001$. Hal ini menunjukan bahwa terapi individu generalis dengan pendekatan strategi pelaksanaan komunikasi efektif dalam menurunkan frekuensi halusinasi pada pasien halusinasi di RSJ H.B Saanin Padang.
\end{abstract}

Kata kunci : halusinasi, komunikasi, terapi individu generalis

\begin{abstract}
Masalah gangguan jiwa yang sering muncul adalah halusinasi. Menurut Maramis (2005) halusinasi adalah gangguan atau perubahan persepsi dimana klien mempersepsikan sesuatu yang sebenarnya tidak terjadi, suatu penerapan panca indra
\end{abstract}

tanpa ada rangsangan dari luar, suatu penghayatan yang dialami suatu persepsi melalui panca indra tanpa stimulus eksteren: persepsi palsu. Pendapat lain juga mengatakan halusinasi adalah sensasi panca indera tanpa adanya rangsangan. Klien 
merasa melihat, mendengar, membau, ada rasa raba dan rasa kecap meskipun tidak ada sesuatu rangsang yang tertuju pada kelima indera tersebut (Izzudin, 2005 dikutip dari Harnawati 2008). Dari data yang diperoleh pada bulan September 2011 dari RSJ Prof. HB. Sa'anin Padang, menunjukkan bahwa dari 169 orang pasien yang dirawat, 87 orang $(57,74 \%)$ diantaranya adalah pasien dengan halusinasi.

Menurut Leksikon (2004), semakin banyak tanda dan gejala halusinasi yang muncul dan semakin tinggi frekuensi halusinasi, dan apabila haluinasi ini mempengaruhi sikap dan perilaku pasien hal ini akan berakibat buruk dan dapat menjurus kepada tindakan maladaptif seperti bunuh diri, perilaku kekerasan, dan mencedrai diri sendiri dan orang lain.

Untuk mengatasi halusinasi dan mengurangi frekuensi halusinasi yang timbul pada pasien halusinasi ini ada dua jenis terapi yang dapat diberikan yang pertama terapi medis berupa pengobatan misalnya Chlorpromazine yang diberikan secara IM, Tranquilaizer misalnya Valium atau Stesolid yang diberikan secara IV, untuk terapi oral obat yang diberikan pada psikosis adalah Triflouperazine (Stelazine) dan haloperidol (Maramis, 2005). Yang kedua terapi modalitas yaitu terapi utama dalam keperawatan jiwa. Terapi ini di berikan dalam upaya mengubah perilaku pasien dari perilaku maladaptif menjadi perilaku adaptif. Tindakan terapi modalitas yang meliputi, terapi keluarga, terapi lingkungan, terapi kognitif, terapi kelompok, terapi perilaku dan terapi individu (Keliat, 2006).

Terapi individu merupakan salah satu bentuk terapi yang dilakukan secara individu oleh perawat kepada pasien secara tatap muka perawat-pasien dengan cara yang terstruktur dan durasi waktu tertentu sesuai dengan tujuan yang ingin dicapai (Akemat, 2004). Pendekatan terapi individu yang sering digunakan adalah pendekatan strategi pelaksanaan komunikasi diantaranya membina hubungan saling percaya perawat-pasien, membantu mengenal halusinasi, dilakukan dengan berdiskusi tentang isi halusinasi (apa yang didengar, dilihat), waktu terjadi halusinasi, frekuensi dan situasi penyebab halusinasi serta respons pasien saat itu, melatih mengontrol halusinasi menggunakan cara menghardik halusinasi, bercakap-cakap dengan orang lain dan melakukan aktivitas terjadwal, mendapat dukungan dari keluarga, menggunakan obat, kemampuan yang dilihat yaitu menjelaskan kembali pentingnya penggunaan obat pada gangguan jiwa, menjelaskan kembali akibat bila obat tidak digunakan sesuai program, menjelaskan kembali akibat bila putus obat, menjelaskan kembali cara mendapatkan obat/berobat dan mampu menjelaskan kembali cara menggunakan obat dengan prinsip 5 (lima) benar (Keliat, 2006). Selain itu, dalam pendekatan strategi pelaksanaan komunikasi ini lebih menekankan kepada teknik menggali perasaan secara dalam dan komprehensif, diantaranya teknik katarsis, teknik sugesti, teknik reassurance, teknik humor, teknik empati, teknik klarifikasi, dan teknik genuineness (Stuart, 2009). Aspek yang terpenting tindakan keperawatan ini adalah menjadikan individu mampu menilai dirinya sendiri tanpa merusak suasana psikologisnya, melepaskan pikiran yang membebani serta memahami pikiran dan perilaku salahnya (Videbeck, 2008).

Menurut Yustinus (2008), mengingat dampak yang ditimbulkan dari halusinasi, maka masalah tersebut memerlukan penanganan lebih lanjut, yaitu dengan memberikan terapi individu dengan pendekatan strategi pelaksanaan komunikasi secara benar, komprehensif dan berkesinambungan, hal ini akan membentuk perkembangan analisis hubungan (transference relationship) antar individu sehingga membuat pasien melepaskan tegangan dan menghidupkan kembali sejumlah kejadian yang mengandung emosi dalam diri pasien. Pendekatan ini bersifat fleksibel, pasien tidak diharuskan berpastisipasi secara kaku, tetapi pasien dapat berpartisipasi dengan cara mereka 
sendiri dan dengan tingkat kemampuan berinteraksi yang berbeda (Yustinus, 2008).

Berdasarkan penelitian yang dilakukan oleh Rivo (2011) di Rumah Sakit Provinsi Sumatera Utara, mengenai kemampuan pasien meningkatkan harga diri rendah yang diberikan terapi individu dengan pendekatan strategi pelaksanaan komunikasi dan terapi kelompok, didapatkan hasil terapi individu dengan strategi pelaksanaan komunikasi lebih efektif meningkatkan harga diri pasien dari terapi kelompok.

Berdasarkan wawancara dengan kepala ruangan Cendrawasih pada tanggal 22 September 2011 terapi individu dengan strategi pelaksanaan komunikasi memang sudah diterapkan, dengan frekuensi minimal 4 kali dalam sehari, 2 kali pada shift pagi dan 2 kali pada shift sore. Pelaksanaan tersebut diawali dengan mengajarkan cara mengontrol halusinasi dengan cara menghardik, selanjutnya mengajarkan cara mengontrol halusinasi dengan bercakapcakap dengan orang lain, mengajarkan cara mengontrol halusinasi dengan melakukan aktifitas terjadwal dan mengajarkan cara mengontrol halusinasi dengan meminum obat.

Dari empat kali per hari pasien mendapat tindakan keperawatan berupa strategi pelaksanaan, namun dalam pelaksanaannya, masih ada aspek-aspek positif pada strategi pelaksanaan yang masih belum dilakukan seperti teknik sugesti, teknik katarsis, dan teknik reassurance dan masih dilaksanakan tidak secara rutin dan berkesinambungan. Selain itu, masih banyak pasien yang masih menunjukkan gejala-gejala halusinasi seperti masih ada pasien yang berbicarabicara sendiri, tertawa sendiri dan masih kelihatan bingung. Menurut Depkes (2005) standar lama hari rawatan pasien dirumah sakit jiwa dengan penanganan terapi yang intensif yaitu selama 14 hari. Berdasarkan fenomena diatas, maka penulis merasa tertarik untuk mengetahui bagaimana pengaruh terapi individu dengan pendekatan strategi pelaksanaan komunikasi terhadap frekuensi halusinasi pada pasien halusinasi di Rumah Sakit Jiwa Prof. HB.Sa'anin Padang.

\section{METODE}

Penelitian ini menggunakan rancangan penelitian Quasi-eksperimental nonequivalen(pretest and posttest) group design. Populasi penelitian ini adalah seluruh pasien dengan halusinasi di ruangan Cendrawasih Rumah Sakit Jiwa H.B Saanin Padang. Jumlah keseluruhan pasien dengan Halusinasi dari bulan Juli, Juni, dan Agustus sebanyak 25 orang. Teknik sampling yang digunakan dalam penelitian ini yaitu purposive sampling. Jumlah sampel yang digunakan pada penelitian ini yaitu 13 orang sampel yang mengalami halusinasi dengan kriteria: berada pada tahap III halusinasi, dan mendapatkan terapi generalis sebelumnya. Penelitian ini tidak mengikutsertakan pasien halusinasi yang berada pada tahap IV. Alat ukur yang digunakan yaitu wawancara langsung secara terstruktur dengan pedoman wawancara baik pre test dan posttest yang dilakukan dengan pasien dengan mewawancarai tentang jenis halusinasi, isi halusinasi, waktu, frekuensi, dan situasi munculnya halusinasi serta mengkaji respon terhadap halusinasi berapa banyak kejadian halusinasi yang dialami oleh pasien dalam satu hari. Waktu penelitian di mulai dari bulan September sampai November 2011. Analisa univariat digunakan untuk menggunakan distribusi frekuensi dari tiap variabel yang yang diteliti. Anlisis bivariat digunakan uji Wilcoxon. Karena nilai $\mathrm{p}<$ 0,05 maka secara statistik disebut bermakna dan jikas nilai $\mathrm{p}>0,05$ maka hasil diperhitungkan tidak bermakna.

\section{HASIL DAN PEMBAHASAN}

Hasil univariat karakteristik responden menunjukkan proporsi responden dilihat dari segi umur lebih dari separuh responden $(61,6 \%)$ memiliki usia antara 19 - 39 tahun, proporsi responden dilihat dari jenis kelamin seluruhnya laki-laki (100\%), dan proporsi responden dilihat dari riwayat 
pekerjaan lebih dari separuhnya $(61,6 \%)$ tidak bekerja. Dilihat dari segi penurunan frekuensi halusinasi sebelum dan sesudah diberikan terapi terdapat 4 orang $(30,7 \%)$ yang mengalami penurunan sebanyak 2 poin terhadap frekuensi halusinasi, dan 9 orang $(69,3 \%)$ yang mengalami penurunan frekuensi halusinasi sebanyak 3 poin (tabel $1)$.

\begin{tabular}{|c|c|c|c|}
\hline $\begin{array}{l}\text { No. } \\
\text { Responden }\end{array}$ & $\begin{array}{c}\text { Sebelum Perlakuan } \\
\text { (Pretest) }\end{array}$ & $\begin{array}{c}\text { Setelah Perlakuan } \\
\text { (Posttest) }\end{array}$ & Kategori \\
\hline 1 & 5 & 3 & $\downarrow 2$ \\
\hline 2 & 6 & 4 & $\downarrow 2$ \\
\hline 3 & 4 & 1 & $\downarrow$ \\
\hline 4 & 6 & 3 & $\downarrow$ \\
\hline 5 & 5 & 2 & $\downarrow$ \\
\hline 6 & 4 & 2 & $\downarrow$ \\
\hline 7 & 6 & 3 & $\downarrow \quad 3$ \\
\hline 8 & 5 & 2 & $\downarrow 3$ \\
\hline 9 & 6 & 3 & $\downarrow \quad 3$ \\
\hline 10 & 4 & 2 & $\downarrow$ \\
\hline 11 & 5 & 2 & $\downarrow$ \\
\hline 12 & 6 & 3 & $\downarrow$ \\
\hline 13 & 5 & 2 & $\downarrow$ \\
\hline
\end{tabular}

Tabel 1. Perubahan rerata frekuensi halusinasi pada pasien halusinasi Di RSJ HB Saanin Padang tahun 2011

\begin{abstract}
Frekuensi halusinasi sebelum pemberian terapi individu dengan pendekatan strategi pelaksanaan komunnikasi adalah 5,15 dengan standar deviasi 0,801 . Sedangkan rata-rata frekuensi halusinasi setelah pemberian terapi individu dengan pendekatan strategi pelaksanaan komunikasi adalah 2,46 dengan standar deviasi 0,776. Hasil uji statistic (Wilcoxon) didapatkan nilai $\mathrm{p}=0,01 \quad(\mathrm{p}<0,05)$, maka dapat disimpulkan terdapat perbedaan perubahan frekuensi halusinasi pasien setelah pemberian terapi individu dengan pendekatan strategi pelaksanaan
\end{abstract} komunikasi.

Hal ini disebabkan sebelum pasien diberikan terapi pasien dipengaruhi oleh factor internal maupun factor eksternal, berupa kurang komunikasi antara perawat dengan pasien sehingga mengakibatkan mekanisme koping pada diri pasien rendah dan pasien tidak mampu untuk mengontrol halusinasi yang dialaminya. Setelah diberikan terapi, pasien sering berkomunikasi dengan perawat, pasien memiliki kemampuan untuk mengontrol halusinasi, meningkatkan kemapuan koping pada pasien sehingga mampu untuk menurunkan frekuensi halusinasi yang ada pada diri pasien.

Seiring dengan teori menurut Nasir (2009) dalam Nasir dan Muhith (2011), strategi pelaksanaan komunikasi berperan penting dalam asuhan keperawatan jiwa, dengan alasan komunikasi mampu mendukung stabilitas emosi pasien, karena dengan komunikasi pasien mampu berhumbungan dengan orang lain dalam memenuhi kebutuhan dasarnya dan pasien juga butuh penguatan untuk 
mempertahankan diri melalui komunikasi yang efektif. Menurut Purba (2009) Terapi ini ini juga dapat membentuk kepercayaan pasien dengan perawat, pasien menyadari bahwa yang dialamanyi tidak ada obyeknya dan harus diatasi, dan pasien mampu mengontrol halusinasinya.

Kunci dari terapi individu dengan pendakatan strategi pelaksanaan komunikasi adalah bagaimana pasien dapat mengungkapkan perasaanya, dapat mengungkapkan perilaku yang diperankannya dan menilainya sesuai dengan kondisi realitas. Essensi dari terapi individu mencakup seluruh aspek kehidupan yang menjadi beban psikisnya. Hal ini memungkinkan dalam proses terapi individu masalah yang terjadi pada pasien akan dieksplorasi oleh perawat sampai pada titik permasalahan yang krusial dan didiskusikan sesuai dengan situasi, kondisi, serta kemampuan yang dimiliki pasien (Nasir dan Muhith, 2011).

Hasil penelitian ini juga sejalan dengan penelitian Elyani (2011) di Rumah Sakit Jiwa Surakarta, menunjukan adanya perubahan yang signifikan antara frekuensi halusiansi sebelum diberikan terapi individu dengan pendekatan strategi pelaksanaan komunikasi dengan sesudah diberikan terapi. Didapatkan nilai $\mathrm{p}=0,00(\mathrm{p}<0,05)$ Ho ditolak.

Menurut analisa peneliti terapi individu dengan pendekatan strategi pelaksanaan komunikasi berpengaruh terhadap perubahan frekuensi halusinasi pada pasien halusinasi, yang terlihat terjadinya penurunan kejadian halusinasi pada pasien halusinasi di RSJ H.B Saanin Padang.

\section{KESIMPULAN \& SARAN}

Nilai rata-rata frekuensi halusinasi sebelum diberikan terapi individu dengan pendekatan strategi pelaksanaan komunikasi yaitu sebesar 5,15. Nilai ratarata frekuensi halusinasi setelah diberikan terapi individu dengan pendekatan strategi pelaksanaan komunikasi yaitu sebesar 2,46. Adanya perbedaan yang signifikan antara sebelum diberikan terapi individu dengan pendekatan strategi pelaksanaan komunikasi dengan setelah diberikan terapi. Peneliti menyarankan bagi perawat RS Jiwa H.B Saanin diharapkan menerapkan terapi individu generalis dengan pendekatan strategi pelaksanaan komunikasi sesuai dengan standar asuhan keperawatan (SAK) yang telah ditetapkan. Selain itu, perlu diadakan sosialisasi SAK agar semua perawat memiliki persamaan persepsi dalam memberikan tindakan keperawatan terhadap pasien. Bagi peneliti selanjutnya untuk dapat melakukan penelitian tentang pengaruh terapi individu generalis dengan pendekatan strategi pelaksanaan komunikasi pada pasien halusinasi terhadap kemampuan pasien dalam mengontrol halusinasinya.

\section{DAFTAR PUSTAKA}

Akemat. (2004). Asuhan keperawatan klien dengan perubahan sensori persepsi: halusinasi. Makalah. Tidak dipublikasikan.

Elyani. (2011). Penelitian yang terkait dengan pengaruh terapi individu terhadap frekuesi halusinasi. diakses melalui http://www.google.com

Harnawati. (2008). Perubahan persepsi sensori.Diakses dari http://www.google. Com tanggal 26 Agustus 2011

Hawari, D. (2001). Manajemen stres , cemas dan depresi. Fakultas Kedokteran UI: Jakarta

Keliat, B. A. (2006). Proses keperawatan kesehatan jiwa. Jakarta: Penerbit Buku Kedokteran EGC

Leksikon. (2004). Terapi individu terhadap frekuensi halusinasi Diakses melalui http://www.google.com.

Maramis, W.F. (2005). Catatan: Ilmu kedokteran jiwa. Surabaya: Airlangga University Press.

Nasir, dkk. (2011). Dasar-dasar keperawatan jiwa: Pengantar dan teori. Jakarta: Salemba Medika

Purba. (2009). Pengantar ilmu komunikasi. Medan: Pustaka Bangsa Press 
NERS JURNAL KEPERAWATAN VOLUME 8, No 1, Juni 2012 : 1-6

Rivo (2011).Penelitian yang terkait tentang frekuensi halusinasi Diakses pada tanggal 12 Desember 2011 dari http://www. Google.com //.

Stuart, \& Laraia.(2001). Principle and practice of psychiatric nursing (6th ed). St. Louis: Mosby Year Book

Yustinus. (2006). Kesehatan mental 3.Jakarta: Kanisius 